\title{
PENGARUH MEDIA PEMBELAJARAN MICROSOFT POWER POINT TERHADAP MINAT BELAJAR MATA PELAJARAN PKN PADA MATERI HAKEKAT DEMOKRASI PESERTA DIDIK KELAS VIII SMP NEGERI 4 PADANGSIDIMPUAN
}

\author{
Yusmiati \\ Dosen FKIP Univeristas Muhammadiyah Tapanuli Selatan
}

\begin{abstract}
Abstrak
Pengaruh Media Pembelajaran Microsoft Power Point Terhadap Minat Belajar Mata Pelajaran PKn Pada Materi Hakekat Demokrasi. Rumusan masalah penelitian ini adalah: “Apakah Media Pembelajaran Microsoft Power point berpengaruh terhadap Minat Belajar mata pelajaran PKn pada materi Hakekat Demokrasi Peserta Didik Kelas VIII SMP Negeri 4 Padangsidimpuan?. Jenis penelitian ini adalah penelitian asosiatif. Penelitian asosiatif adalah penelitian yang bertujuan untuk mengetahui hubungan antara dua variabel atau lebih, dengan populasi seluruh siswa kelas VIII SMP negeri 4 Padangsidimpuan yang berjumlah 426 peserta didik yang terdiri dari 15 kelas, sedangkan sampel ditetaapkan secara acak $10 \%$ dari jumlah populasi dengan jumlah 42 peserta didik. Rumus menguji hipotesis yang dipergunakan adalah rumus product momennt. Hasil analisis menunjukkan bahwa Dari hasil perhitungan koefesien korelasi maka diperoleh $r_{x y}=0$,992. Jika angka indek korelasi tersebut di korelasikan dengan “ $r$ " tabel product moment maka di dapat bahwa pada taraf signifikan 5\% dengan $n=42$ diperoleh 0,304. Dengan demikian dapat diketahui bahw nilai $r_{x y}$ hitung lebih besar dari pada $r$ table yakni :0,992>0,304. Dengan demikian hipotesis alternatif ( $\mathrm{Ha}$ ) dapat di terima kebenarannya, yaitu Media Pembelajaran Microsoft Power Point berpengaruh terhadap minat belajar mata pelajaran PKn pada materi Hakekat Demokrasi. Besarnya pengaruh sebesar $99 \%$

Kata Kunci: Model pembelajaran, Microsoft Power point, Minat Belajar
\end{abstract}

\section{Pendahuluan}

Media merupakan komponen sumber belajar atau wahana fisik yang mengandung materi intruksional di lingkungan peserta didik yang dapat meningkatkan minat peserta didik dalam belajar. Selain harus menguasai materi seorang guru juga harus mampu menciptakan kreativitas baik dalam 
menggunakan media maupun model dalam proses pembelajran hal ini dimaksudkan agar pembelajaran tidak menonton dan tidak membosankan sehingga peserta didik akan merasa senang dan tertarik untuk mengikuti pembelajaran dan kedatangan guru pun dirindukan.

Dampak perkembangan iptek terhadap proses pembelajaran adalah diperkayanya sumber dan media pembelajaran, seperti buku teks, modul, flim, vidio, web, dan sebagainya.

Untuk dapat mengimbangi adanya perkembangan tegnologi dan perubahaan zaman tersebut, maka di perlukan programprogram pendidikan yang sengaja mengantisipasi perkembangan teknologi dan perubahan zaman, karena hanya melalui usaha pendidikan dapat tercipta sumberdaya yang berkualitas dan handal yang mampu menyikapi segala perkembangan ilmu pengatahuan dan tegnologi yang sangat cepat.

Pendidikan Kewarganegaraan adalah sebagai salah satu bidang ilmu dalam dunia pendidikan juga merupakan salah satu bidang studi yang sangat penting, baik bagi peserta didik maupun bagi pengembangan bidang keilmuan yang lain. Didalam proses pembelajaran khususnya Pendidikan Kewarganegaraan, guru juga harus dapat meningkatkan minat belajar pesertadidik. Melihat proses belajar Pendidikan Kewarganegaraan yang selama ini berlangsung, bahwa proses pembelajaran yang terjadi masih berfokus pada guru sebagai sumber utama pengatahuan.
Berdasarkan pengamatan penulis bahwa di SMP Negeri 4 Padangsidimpuan pada mata pelajaran PKn ditetapkan pada jam-jam terahir sehingga peserta didik tersebut akan merasa bosan dan jenuh berada di dalam kelas dan ditambah lagi materi yang di jelaskan oleh kurang menarik hingga membuat peserta didik mengantuk dan tidak bersemangat lagi dalam mengikuti pembelajaran, dan guru masih banyak menggunakan metode ceramah. Guru lebih banyak memberikan materi dan menjelaskannya berdasarkan kajian yang terdapat pada buku pegangan.

Hal ini apabila di biarkan akan berdampak pada prestasi belajar peserta didik terutama pada mata pelajaran $\mathrm{PKn}$, oleh karena itu seorang guru merupakan faktor yang sangat dominan yang seharusnya memiliki prilaku dan kemampuan yang memadai untuk mengembangkan peserta didik secara utuh, karena tugas-tugas guru bukan saja mengajar semata tetapi guru harus berusaha mengembangkan kemampuan peserta didik secara kogniotif, afektif, maupun, psikomotor, melalui peningkatan prestasi belajar peserta didik.

Di zaman sekarang ini komputer merupakan produk teknologi yang serba bisa dan sudah menjadi kebutuhan manusia, yang kini sudah dapat digunakan sebagai media pembelajaran untuk mengajarkan materi PKn. Salah satu program komputer yang memiliki fasilitas untuk membuat animasi, menyajikan gambar, menyajikan tulisan dan dapat dipersentasikan adalah program aplikasi Microsoft Power Point. Program ini dapat digunakan sebagai media 
pembelajaran karena dapat membantu guru dalam menyampaikan materi pembelajaran PKn.

Dengan menggunakan media pembelajaran Microsoft Power Point diharapkan peserta didik lebih mudah memahami materi pembelajaran dan termotivasi untuk giat dalam mengikuti kegiatan pembelajaran dan peserta didik pun akan lebih kreatif dalam belajar. Objek yang ditampilkan dalam power point ini lebih konkret karena penyajiannya yang variatif karena terdapat aplikasi gambar, animasi, audio, teks, dan tabel sehingga membuat proses pembelajaran lebih menarik, efektive dan tidak menjenuhkan dan tercpainya tujuan pembelajaran.

Berdasarkan uraian di atas, penulis akan mencoba melakukan penelitian dengan judul: " Pengaruh Media Pembelajaran Microsoft Power Poin Terhadap Minat Belajar Mata Pelajaran PKn Pada Materi Hakekat Demokrasi Peserta Didik Kelas VII SMP Negeri 4 Padangsidimpuan.

\section{Metode Penelitian}

Penelitian ini menggunakan pendekatan kuantitatif dengan metode korelasional, yaitu penelitian yang bersifat menghubungkan antara beberapa variabel secara bersama-sama maupun secara sendiri mempengaruhi variabel lain, dan untuk mengetahui pengaruh variabel -variabel bebas terhadap variabel terikat. Jadi penelitian ini untuk mengetahui pengaruh antar dua variabel yang berbeda, yaitu variabel $\mathrm{X}$ dan variabel $\mathrm{Y}$. Variabel $\mathrm{X}$ adalah media Pembelajaran Microsoft power point dan variable $\mathrm{Y}$ adalah minat belajar peserta didik dalam mata pelajaran PKn pada materi Hakekat Demokrasi.

\section{Pembahasan dan Hasil}

Setelah penulis memperoleh data tentang kedua variabel yaitu variabel $\mathrm{X}$ Penggunanaan media microsoft Power Point dan variabel $\mathrm{Y}$ minat belajar siswa materi Hakekat Demokrasi, maka langkah selanjutnya melakukan analisis data untuk menguji hipotesis. Hipotesis berbunyi : Media Pembelajaran Microsoft Power point berpengaruh terhadap Minat Belajar Mata Pelajaran PKn Pada Materi Hakekat Demokrasi Peserta Didik Kelas VIII SMP Negeri 4 Padangsidimpuan. Dalam menguji hipotesis dilakukan dengan menggunakan rumus product moment.

Dari perhitungan koefesien korelasi maka diperoleh $\mathrm{r}$ hitung adalah adalah 0,968. Hasil ini kemudian dibandingkan dengan $\mathrm{r}$ tabel dengan $\mathrm{n}=42$ pada taraf kesalahan $5 \%$, yaitu nilai r tabel 0,304. Jadi dapat diketahui bahwa $r$ hitung lebih besar dari $r$ tabel yaitu 0,992> 0,304 (taraf kesalahan 5\%), 0,992> 0,3943 (pada taraf kesalahan 1\%). Untuk menguji kebenaran hipotesis dilakukan dengan ketentuan membandingkan nilai $r$ hitung dengan nilai $r$ tabel. Apabila nilai $\mathrm{r}$ hitung lebih besar atau sama dengan $r$ tabel maka hipotesis alternatif $\mathrm{Ha}$ diterima, dan hipotesis $\mathrm{Ho}$ ditolak, sebaliknya apabila nilai $r$ hitung lebih kecil dari $r$ tabel maka hipotesis alternatif ( $\mathrm{H} \mathrm{a}$ ) ditolak dan Ho diterima.

Berdasarkan ketentuan tersebut maka dapat dilihat bahwa $r$ hitung lebih besar dari nilai r tabel, maka Hipotesis alternative (Ha) 
dapat diterima kebenarannya. Artinya Media Pembelajaran Microsoft Power point berpengaruh terhadap Minat Belajar Mata Pelajaran PKn Pada Materi Hakekat Demokrasi Peserta Didik Kelas VIII SMP Negeri 4 Padangsidimpuan Tahun Pelajaran 2015-2016”.

Untuk mengetahui derajat tingkat korelasi diperlukan kriteria. Kreteria yang digunakan seperti yang dikemukakan oleh Arikunto (2006:195). Dari perhitungan kofesien korelasi $\mathrm{r}$ hitung adalah 0,992 dan dihubungkan dengan derajat tingkat korelasi, maka berada pada tingkat pengaruh tinggi.

\section{Kesimpulan}

Berdasarkan Hasil penelitian dan analisis data, maka dapat diambil beberapa kesimpulan sebagai berikut:

1. Media Media Pembelajaran Microsoft Power point berpengaruh terhadap Minat Belajar Mata Pelajaran PKn Pada Materi Hakekat Demokrasi Peserta Didik Kelas VIII SMP Negeri 4 Padangsidimpuan. Dari perhitungan kofesien korelasi diperoleh $r$ hitung sebesar 0,992. Melihat daftar tabel kritik product momment dengan jumlah sampel sebanyak 42 orang peserta didik dengan taraf kepercayaan $95 \%$ adalah 0,3024. Sesuai dengan dasar pengambilan keputusan, bahwa terima Ha jika r hitung lebih besar atau sama dengan $r$ tabel, dan terima Ho jika $r$ hitang llebih kecil dar $r$ tabel. Berdasarkan perhitungan maka $r$ hitung lebih besar dari $r$ tabel aatau 0,992 $>$ 0,3024, sehingga Ha diterima.
2. Pengaruh Media Pembelajaran Microsoft Power point terhadap Minat Belajar Mata Pelajaran PKn Pada Materi Hakekat Demokrasi Peserta Didik Kelas VIII SMP Negeri 4 Padangsidimpuan sebesar $98 \%$, berada pada tingkat pengaruh tinggi. Hal ini beraert minat belajar siswa dapat ditingkatkan melalui penggunaan media Pembelajaran Microsoft Power point.

\section{Saran}

Penulis mencoba mengajukan berbagai saran demi perbaikan kedepan, yaitu :

1. Kepada guru yang mengajar diharapkan dapat meningkatkan minat siswa dalam belajar PKn dengan melalui peningkatkan penggunaan media pembelajran Microscofl Point .

2. Kepada peserta didik yang merupakan subjek belajar untuk lebih meningkatkan minat terhadap materi pelajaran sehingga penguasaan pembelajaran dapat tercapai dengan baik.

\section{Daftar Pustaka}

Arikunto,Suharsimi.2006.Prosedur Penelitian.Jakarta:Rineka Cipta

Asmana, Jama Ma’mur.2011.Peneliti n Pendidikan.Jakarta: Diva Press

Azhar,Arsyad,2011. Media Pembelajaran. Jakarta:Raja Grafindo Persada

Azwar, Syaifuddin.2010. Model Penelitian.Yogyakarta:Pustaka Pelajar 
Bungin,Burhan.2005.Metode

Penelitian Kuantitatif. Jakarta:Kencana

Cart Safran dan Sukardi. 2005. Bimbingan Dan Penyuluhan Belajar

Disekolah. Bandung: Usaha Nasional

Cecep Kustandi,Dkk.2011.Media

Pembelajaran Digital Dan Manual.Jakarta:

Ghalia

Djamarah dkk. 2010. Strategi

Belajar Mengajar. Jakarta: Rineka Cipta

Hamdan,M.A. 2011. Strategi Belajar

Mengajar. Bandung: Pustaka Setia

Kethut.2010.Modul Pembuatan

Media Presentase Jakarta: Pusatteknologi

Dan Komunikasi Pendidikan Kementerian Pendidikan

Komalasari,Kokom.2008.Pembelaja ran Kontekstual: Konsep Dan Aplikasi. Bandung:; PT Refika

Kurniawan Benny. 2012. Pendidikan Kewarganegaraan Untuk Mahasiswa. Tangerang: Jelajah Nusa.

Sagala,Syaiful.2006. Konsep Dan Makna Pembelajaran.Bandung: Alfabeta

Syarif Kemala. 2014. Perkembangan Peserta Didik. Medan: UNIMED Press. 